\title{
Cardiovascular effects of radiotherapy on the patient with cancer
}

\author{
Leonardo Augusto Robert Moreira ${ }^{1}$, Eduardo Nani Silva², Mario Luiz Ribeiro ${ }^{3}$, Wolney de Andrade Martins ${ }^{4 *}$

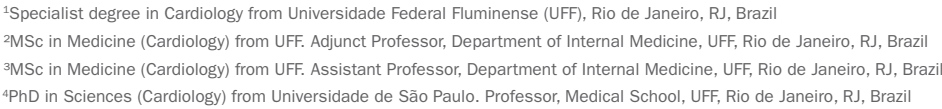

\begin{tabular}{r}
\hline \\
Study conducted at Curso de \\
Pós-graduação em Ciências \\
Cardiovasculares da Universidade Federal \\
Fluminense (UFF), Niterói, RJ, Brazil \\
Article received: $7 / 5 / 2014$ \\
Accepted for publication: $10 / 21 / 2014$ \\
*Correspondence: \\
No andar, Centro \\
Niterói, RJ - Brazil \\
Postal code: $24030-215$ \\
wolney_martins@hotmail.com \\
Financial support: The Cardio-oncology \\
Study Group of UFF receives incentives \\
for research projects from the Carlos \\
Chagas Filho Foundation for Support \\
of Research in the State of Rio \\
de Janeiro (Faperj)
\end{tabular}

\section{SUMMARY}

The incidence of cancer (CA) has increased globally and radiotherapy (RT) is a vital component in its treatment. Cardiovascular injuries induced by RT in the treatment of thoracic and cervical CA have been causing problems in clinical practice for decades, and are among the most serious adverse effects of radiation experienced by the growing number of cancer survivors. This article presents a review on the Lilacs, Scielo and Pubmed databases of the main cardiovascular injuries, their mechanisms, clinical presentations, treatments and prevention proposals. Injuries caused by RT include diseases of the pericardium, coronary artery disease, valvular disease, myocardial disease with systolic and diastolic dysfunction, conduction disorders, and carotid artery and great vessels disease. Thoracic and cervical irradiation increases cardiovascular morbidity and mortality. Despite the great progress in the improvement of RT techniques, totally excluding prime areas of the cardiovascular system from the irradiation field is not yet possible. Guidelines must be created for monitoring, diagnosis and treatment of patients with CA treated with RT.

Keywords: Radiotherapy, radiation injuries, cardiovascular diseases.

\section{INTRODUCTION}

Cancer (CA) is characterized by uncontrolled cell proliferation that expresses varying degrees of differentiation to the precursor cells. In general, CA has a natural and irreversible history and autonomous growth, which persists even after cessation of the stimulus that produced it. CA has the property of invading adjacent tissues and causing metastasis, where subpopulations of malignant cells grow and invade tissues again. ${ }^{1}$

According to global estimates by the Globocan project of the International Agency for Research on Cancer and the World Health Organization, in 2012 there were 14.1 million new cases of CA and 8.2 million deaths due to this disease worldwide. For 2030, the estimated global incidence of CA is 21.4 million cases and $13 .{ }^{2}$ million deaths. In Brazil, the estimate for the period 2014-2015 is approximately 576,000 new cases of CA including non-melanoma skin cancer. Chart 1 contains the estimated incidence of the main thoracic and cervical tumors for Brazil in 2014 according to the National Cancer Institute. $^{2}$
CHART 1 Estimated new cases of cancer in the cervical or thoracic sites for the year 2014 in Brazil. Source: Instituto Nacional do Câncer. ${ }^{2}$

\begin{tabular}{ll} 
Cancer's primary location & Estimated new cases \\
\hline Female breast & 57,120 \\
\hline Trachea, bronchi and lungs & 27,330 \\
\hline Larynx & 7,640 \\
\hline Esophagus & 10,780 \\
\hline Hodgkin's lymphoma & 2,180 \\
\hline Thyroid & 9,200 \\
\hline Stomach & 20,390 \\
\hline
\end{tabular}

Radiation therapy (RT) is a vital component in the treatment of CA. It arose from the discovery of $x$-rays by Wilhelm Röentgen in 1895, and radioactivity, by Henry Becquerel, in 1896. When radiation interacts with the air or matter, it transfers a sufficient amount of power to the electrons of the medium to rip them from the atom. This process is called ionization. The density of this process depends on the charge, the mass and the speed of the 
particles. The biological effects of radiation can be direct or indirect. It is considered a direct effect when interacting with the cellular components, proteins and lipids, causing them to undergo structural changes. In indirect interaction, the effect occurs in the medium where the cells and their constituents are suspended, that is, water, with the production of free radicals. Free radicals are atoms or molecules that are unstable and highly reactive. Seeking an electronic balance causes the free radicals to break chemical bonds in search of an electron. The biological response to irradiation can lead to a large number of changes like breakage to double-stranded DNA, chromosome rearrangements and breakage, translocation of lipid molecules in the membrane, death by apoptosis or cell division, mutation and carcinogenesis. ${ }^{3}$

Radiation therapy is an important component of the therapeutic arsenal for the treatment of breast CA, Hodgkin's disease, lung CA and other tumors involving the cervical and thoracic regions and is linked to increased cardiovascular morbidity and mortality. Concerns about cardiovascular lesions (CV) induced by RT in patients irradiated for treatment of cervical and thoracic cancers have occurred for decades. ${ }^{4,5}$ Cardiovascular morbidity and mortality is proportional to the dose of radiation and the site exposed in the $\mathrm{CV}$ unit. ${ }^{6-12}$ Therapeutic advances for clinical control or curing of CA and better support for treatment-related complications have provided a greater survival rate to patients, with enough time to develop late-onset cardiovascular sequelae from $\mathrm{RT} .{ }^{13}$ The cardiac effects of RT in the long term are heterogeneous and include coronary artery disease, valve disease; diseases of pericardium; myocardial diseases, with systolic and diastolic dysfunction in particular; and conduction system disturbances. ${ }^{14}$ Major vessels and carotid arteries may also be involved. ${ }^{14,15}$

\section{Damage to the Pericardium}

The most common cardiac abnormality resulting from thoracic irradiation, especially of the mediastinum, is pericardial damage that manifests as fibrous thickening and serofibrinous effusion that can progress to cardiac tamponade and/or constrictive pericarditis. ${ }^{13,16}$ Independent clinical factors that may predict the predisposition to pericardial damage have not yet been identified. ${ }^{17,18}$ In the past, pericardial disease induced by radiation has been underestimated. The treatment applied was pericardiocentesis in those that evolved with cardiac tamponade, which resulted in increased mortality. It was assumed that pericardial effusion accounted for the severity of the coexistent illness and not the cardiotoxic effect secondary to radiotherapy. In patients who develop pericardial thickening, associated with pericardial effusion or otherwise, in which is there is an increase in the final diastolic pressure of the right chambers evidenced via cardiac catheterization, the best treatment is pericardiectomy, given that the central venous pressure is reduced to normal immediately after the procedure, in addition to good clinical evolution with disappearance of the symptoms of cardiac dysfunction. ${ }^{19}$ However, in patients with pericardial thickening without high intracavitary pressures, rigorous clinical monitoring seems appropriate. Simple drainage of the effusion is not recommended because the disease can evolve with more marked fibrosis and consequent constriction, meaning that it appears reasonable to remove the maximum possible parietal pericardium. ${ }^{19}$

\section{Coronary artery disease}

Incidental exposure of the heart to RT increases the incidence of accelerated or premature coronary artery disease (CAD), ${ }^{20-22}$ commonly identified in young or relatively young patients with none of the major risk factors for atherogenesis, such as smoking, diabetes mellitus, dyslipidemia, hypertension and a family history of early atherosclerosis. ${ }^{16,21,23} \mathrm{CAD}$ risk begins to increase during the first five years after irradiation and continues for at least 20 years. ${ }^{21,22}$ There is no statistically significant difference between patients with or without risk factors for $\mathrm{CAD}$ at the time of radiotherapy. ${ }^{22}$ The increase in CAD is directly proportional to the average dose of radiation and heart volume included in the RT field. ${ }^{20,22-24}$ The obstructive lesions of the epicardial vessels are most often proximal and in more than $80 \%$ of the cases the lesion occurs in the coronary artery. This can affect the coronary ostia. ${ }^{14,16,20,24,25}$ as they occupy the region with greatest risk of being included in the irradiation fields. ${ }^{20}$ Under microscopy it is possible to observe fibrointimal thickening, fibroproliferative lesions, fibrocalcific and also fibrolipid plaques in the areas of coronary stenosis. ${ }^{13}$ The plaques in irradiated patients are more fibrous with little lipid content. ${ }^{26}$

Some factors such as more frequent proximal impairment affecting the trunk of the left coronary artery and proximal anterior descending artery, and the high prevalence of associated significant valvular disease lead many patients to being recommended for cardiac surgery. However, the results of such treatment do not necessarily correspond to what would be expected in a population that has not been irradiated. In the postoperative period of patients with lesions from RT there is longer hospitalization time, incidence of atrial fibrillation, pacemaker im- 
plantation, as well as higher mortality in the short and long-term. ${ }^{14}$ Many surgeons declare that they are discouraged from using the internal thoracic arteries as a graft in patients with a history of chest radiation; however, the clinical course is comparable, in the medium term, to patients with no history of irradiation. ${ }^{27}$

\section{Damage to the myocardium}

Clinical manifestations of cardiovascular injury due to RT often take many years, if not decades, to manifest. However, sub-clinical lesions have been identified within six months of the end of treatment. ${ }^{25,28}$ Myocardial damage has been identified early through scintigraphic studies with images of myocardial perfusion performed six months after RT in patients treated for left breast CA. Currently, RT techniques with tangential photon beams are used with prior planning using three-dimensional computed tomography in order to minimize such damage. However, any dose of radiation always affects the heart, mainly in the anterior wall of the left ventricle. ${ }^{25,28}$ Perfusion defects are found in approximately $40 \%$ of patients 6 to 24 months after RT for left breast CA and these defects are more prevalent in patients with a higher heart volume within the radiation field. ${ }^{28}$

Perfusion defects after irradiation of a small fraction of the myocardium are caused by damage to the microvasculature. Ionizing radiation causes damage to the endothelial cells of the capillaries with consequent capillary edema, obstruction of the lumen of the vessel and subsequent myocardial fibrosis, ${ }^{25}$ as a result this leads to sub-clinical functional abnormality of the left ventricle. ${ }^{28}$ In addition to the microvascular damage, there is also direct damage from the radiation over the cardiomyocytes. ${ }^{13}$ In histopathological studies, the most common microscopic fibrosis patterns are pericellular and perivascular. Pericellular interstitial fibrosis findings support the hypothesis of early capillary damage causing diffuse ischemia and fibrosis. ${ }^{13}$

A high frequency of diastolic dysfunction of the left ventricle has been demonstrated by echocardiography in asymptomatic patients who have received at least 35Gy of mediastinal irradiation for treatment of Hodgkin's disease. Diastolic dysfunction is explained via histopathology demonstrating fibrosis resulting from microvascular damage. Ischemia induced by cardiac stress tests are more common in these patients and probably CAD is also involved as a cause of diastolic dysfunction associated with significant morbidity. ${ }^{29,30}$ Less frequent than diastolic dysfunction, left ventricular systolic dysfunction is also reported at higher than expected frequency in patients with a history of RT, even if asymptomatic. ${ }^{14,31}$

\section{VALVULAR DAMAGE}

Valvular damage is often found in patients undergoing chest RT probably due to direct damage from the radiation on valvular tissue, since they are not vascularized. The lesions are characterized by diffuse fibrosis of the cusps, with or without calcification. ${ }^{13}$ Initially there is a valvular thickening without clinical repercussions that can be identified by echocardiography in the first decade after RT. It affects one or more valves and evolves gradually, either through worsening of pre-existing damage or appearance of new damage. ${ }^{32}$ Clinically significant valvular dysfunction has been described, on average, 22 years after RT in survivors of Hodgkin's disease. ${ }^{28}$ Consistently, more severe valvular lesions are present on the left side of the heart valves, as these areas have increased hemodynamic stress. Aortic stenosis is the predominant lesion..$^{14,15,33}$

\section{Electrical AND CONDUCTION SYSTEM DISTURBANCES}

As already described for other tissues, radiation also causes damage and scarring to the conduction system. Changes in the electrocardiogram such as conduction defects, $\mathrm{T}$ wave abnormalities and arrhythmias have been reported and may indicate myocardial damage or damage directly to the conduction system. The right branch block is more commonly observed than the left. The initial changes can develop into complete atrioventricular block, suggesting progressive damage. ${ }^{24,30,34,35}$ Among the ventricular repolarization abnormalities, electrocardiographic changes that have been observed are T-wave flattening, deformity or inversion, with higher incidence six months after RT. These changes present greater magnitude in the precordial derivations. ${ }^{36}$

\section{Changes to the Carotid arteries and other VESSELS}

An increased risk of stroke secondary to carotid artery disease has been reported in patients with a history of cervical irradiation, especially when it occurs at an age group in which the atherosclerotic disease of the carotid artery would not be expected. ${ }^{15,37} \mathrm{~A}$ study that used a duplex scan of the carotid arteries in patients between 18 and 37 years of age who received cervical RT due Hodgkin's lymphoma, all in remission and asymptomatic, with more than five years since the end of treatment compared with a control group of healthy and age-matched volunteers identified focal or generalized abnormalities of the intima-media layer (26\% in the study group versus $3 \%$ in the control group), such as fatty streaks, irregularities and discontinuities in the layers, microcalcifications, graininess and initial plaques 
smaller than $2 \mathrm{~mm}$ of common carotids and proximal internal sections of the carotid artery. However, the clinical significance of these changes is unclear, which could be answered in future long term follow-up studies. ${ }^{38}$ Nevertheless, patients with severe carotid obstructive disease referred for surgery and a history of cervical radiation therapy often represent a challenge for the vascular surgeon since there is abnormal adherence of the intima and all layers, obliterating anatomical plans and making endarterectomy technically difficult. Therefore, stent implant angioplasty is increasingly frequent in these patients. ${ }^{39}$

Another late-onset sequela associated with cervical radiation is chronic failure of the baroreflex manifested by labile hypertension and orthostatic intolerance. Histopathological studies have shown atherosclerotic changes, perivascular fibrosis and thickening in the carotid sinus after cervical radiation. Chronic failure of the baroreflex has been attributed to these changes. ${ }^{40}$

Diffuse calcification of the thoracic aorta and stenotic lesions of the subclavian arteries have also been reported. These are late-onset sequelae attributed to adjuvant $\mathrm{RT}$, and it has become well-known that all arteries are sensitive to the late-onset effects of radiation. ${ }^{14,15,41-43}$

\begin{tabular}{|c|c|}
\hline $\begin{array}{l}\text { Cardiovascular } \\
\text { structures } \\
\text { irradiated }\end{array}$ & Major clinical presentations \\
\hline \multirow[t]{4}{*}{ Pericardium } & Pericardial thickening \\
\hline & Pericardial effusion \\
\hline & Cardiac tamponade \\
\hline & Constrictive pericarditis \\
\hline \multirow{2}{*}{$\begin{array}{l}\text { Coronary artery } \\
\text { disease }\end{array}$} & Obstructive lesion in the anterior descending artery \\
\hline & Obstructive lesion in the coronary ostia \\
\hline Myocardium & Asymptomatic left ventricular diastolic dysfunction \\
\hline \multirow[t]{2}{*}{ Valves } & $\begin{array}{l}\text { Valvular thickening without hemodynamic } \\
\text { repercussions }\end{array}$ \\
\hline & Aortic stenosis \\
\hline \multirow{4}{*}{$\begin{array}{l}\text { Cardiac electrical } \\
\text { and conduction } \\
\text { disorders }\end{array}$} & Right bundle branch block (more frequent) \\
\hline & Left bundle branch block \\
\hline & Complete atrioventricular block \\
\hline & T-wave flattening or inversion \\
\hline \multirow{4}{*}{$\begin{array}{l}\text { Great vessels of } \\
\text { the chest }\end{array}$} & Increased carotid intima-media thickness \\
\hline & $\begin{array}{l}\text { Chronic baroreflex failure: labile hypertension or } \\
\text { orthostatic hypotension }\end{array}$ \\
\hline & Aortic calcification \\
\hline & Stenotic lesions of the subclavian arteries \\
\hline
\end{tabular}

\section{Conclusion}

It is evident that chest and cervical radiation has an impact on cardiovascular morbidity and mortality. Despite the major developments in the improvement of radiotherapy techniques and better knowledge and mastery of radiation in recent decades, it has not yet been possible to completely exclude important areas of the cardiovascular system from irradiation fields. More effective and less toxic therapy should be sought. Guidelines must be created for strict monitoring of patients who have had exposure of the cardiovascular system to radiation, especially when it comes to young people with a long life expectancy, given that cardiovascular damage is treated with limited results.

\section{Resumo}

Efeitos cardiovasculares da radioterapia no paciente com câncer

A incidência de câncer (CA) tem aumentado globalmente e a radioterapia (RT) é um componente vital do tratamento. As lesões cardiovasculares induzidas pela RT no tratamento de CA torácicos e cervicais geram problemas à prática clínica há décadas e estão entre os efeitos adversos mais graves da RT experimentados pelo crescente número de sobreviventes de CA. Neste artigo, realiza-se revisão nas bases Lilacs, Scielo e Pubmed das principais lesões cardiovasculares secundárias à RT, os mecanismos fisiopatológicos, as apresentações clínicas, os tratamentos e as propostas de prevenção. Dentre as lesões pela RT, destacam-se as doenças do pericárdio, a doença arterial coronariana, a doença valvular, a doença do miocárdio com disfunção sistólica e diastólica, os distúrbios de condução, a doença das artérias carótidas e dos grandes vasos. A irradiação torácica e cervical aumentam a morbimortalidade cardiovascular. Apesar da grande evolução no aprimoramento das técnicas de RT, ainda não foi possível excluir totalmente áreas nobres do sistema cardiovascular dos campos de irradiação. Faz-se necessária a instituição de diretrizes para monitoramento, diagnóstico e tratamento dos pacientes com CA submetidos à RT.

Palavras-chave: radioterapia, lesões por radiação, doenças cardiovasculares.

\section{References}

1. Kumar V, Abbas AK, Fausto N, Aster JC. Robbins and Cotran Patologia Bases patológicas das doenças. 8.ed. São Paulo: Elsevier, 2010. 
2. Brasil. Ministério da Saúde. Instituto Nacional de Câncer José Alencar Gomes da Silva (INCA). Estimativa 2014 - Incidência de Câncer no Brasil. Rio de Janeiro: INCA, 2014.

3. Bifulco VA, Fernandes Jr HJ, Barbosa AB. Câncer uma visão multiprofissional Barueri: Manole, 2010.

4. Hartman FW, Bollinger A, Doub HP, Smith FJ. Heart lesions produced by the deep X-ray: an experimental and clinical study. Trans Am Clin Climat Assoc. 1927; 43:54-71

5. Hurst DW. Radiation fibrosis of pericardium, with cardiac tamponade: case report with post-mortem studies and review of literature. Can Med Assoc J. $1959 ; 81: 377-80$

6. Bouillon K, Haddy N, Delaloge S, Garbay JR, Garsi JP, Brindel P, et al. Longterm cardiovascular mortality after radiotherapy for breast cancer. J Am Coll Cardiol. 2011; 57(4):445-52.

7. Bouchardy C, Rapiti E, Usel M, Majno SB, Vlastos G, Benhamou S, et al. Excess of cardiovascular mortality among node-negative breast cancer patients irradiated for inner-quadrant tumors. Ann Oncol. 2010; 21(3):459-65.

8. Gyenes G, Rutqvist LE, Liedberg A, Fornander T. Long-term cardiac morbidity and mortality in a randomized trial of pre and postoperative radiation therapy versus surgery alone in primary breast cancer. Radiother Oncol. 1998; 48(2):185-90

9. Darby S, McGale P, Peto R, Granath F, Hall P, Ekbom A. Mortality from cardiovascular disease more than 10 years after radiotherapy for breast cancer: nationwide cohort study of 90,000 Swedish women. Br Med J. 2003; 326(7383):256-7.

10. Hooning MJ, Botma A, Aleman BMP, Baaijens MHA, Bartelink H, Klijn JGM, et al. Long-term risk of cardiovascular disease in 10-year survivors of breast cancer. J Natl Cancer Inst. 2007; 99(5):365-75.

11. Daher IN, Daigle TR, Bhatia N, Durand JB. The prevention of cardiovascular disease in cancer survivors. Tex Heart Inst J. 2012;39(2):190-8.

12. Lee CK, Aeppli D, Nierengarten ME. The need for long-term surveillance for patients treated with curative radiotherapy for Hodgkins disease: University of Minnesota experience. Int J Radiat Oncol Biol Phys. 2000; 48(1):169-79.

13. Veinot JP, Edwards WD. Pathology of radiation-induced heart disease: a surgical and autopsy study of 27 cases. Hum Pathol. 1996; 27(8):766-73.

14. Wu W, Masri A, Popovic ZB, Smedira NG, Lytle BW, Marwick TH, et al. Long-term survival of patients with radiation heart disease undergoing cardiac surgery: a cohort study. Circulation. 2013; 127(14):1476-85.

15. Hull MC, Morris CG, Pepine CJ, Mendenhall NP. Valvular dysfunction and carotid, subclavian, and coronary artery disease in survivors of Hodgkin lymphoma treated with radiation therapy. JAMA. 2003; 290(21):2831-7.

16. Piovaccari G, Ferretti RM, Prati F, Traini AM, Gobbi M, Caravita L, et al. Cardiac disease after chest irradiation for Hodgkins disease: incidence in 108 patients with long followup. Int J Cardiol. 1995; 49(1):39-43.

17. Fukada J, Shigematsu N, Ohashi T, Shiraishi Y, Takeuchi H, Kawaguchi O, et al. Pericardial and pleural effusions after definitive radiotherapy for esophageal cancer. J Radiat Res. 2012; 53(3):447-53.

18. Cosset JM, Henry-Amar M, Pellae-Cosset B, Carde P, Girinski T, Tubiana M, et al. Pericarditis and myocardial infarctions after Hodgkins disease therapy. Int J Radiat Oncol Biol Phys. 1991; 21(2):447-9.

19. Morton DL, Glancy DL, Joseph WL, Adkins PC. Management of patients with radiation induced pericarditis with effusion: a note on the development of aortic regurgitation in two of them. Chest. 1973; 64(3):291-7.

20. Correa CR, Litt HI, Hwang WT, Ferrari VA, Solin LJ, Harris EE. Coronary artery findings after left-sided compared with right-sided radiation treatment for early-stage breast cancer. J Clin Oncol. 2007; 25(21):3031-7.

21. Aleman BM, van den Belt-Dusebout AW, De Bruin ML, van 't Veer MB, Baaijens $\mathrm{MH}$, de Boer, et al. Late cardiotoxicity after treatment for Hodgkin lymphoma. Blood. 2007; 109(5):1878-86.

22. Darby SC, Ewertz M, McGale P, Bennet AM, Blom-Goldman U, Bronnum $\mathrm{D}$, et al. Risk of ischemic heart disease in women after radiotherapy for breast cancer. N Engl J Med. 2013; 368:987-98.

23. Evans ES, Prosnitz RG, Yu X, Zhou SM, Hollis DR, Wong TZ, et al. Impact of patient specific factors, irradiated left ventricular volume and treatment set-up errors on the development of myocardial perfusion defects after radiation therapy for left-sided breast cancer. Int J Radiat Oncol Biol Phys 2006; 66(4):1125-34

24. Orzan F, Brusca A, Conte MR, Presbitero P, Figliomeni MC. Severe coronary artery disease after radiation therapy of the chest and mediastinum: clinical presentation and treatment. Br Heart J. 1993; 69(6):496-500.

25. Lind PA, Pagnanelli R, Marks LB, Borges-Neto S, Hu C, Zhou SM, et al Myocardial perfusion changes in patients irradiated for left-sided breast cancer and correlation with coronary artery distribution. Int $\mathrm{J}$ Radiat Oncol Biol Phys. 2003; 55(4):914-20.

26. Brosius FC, Waller BF, Roberts WC. Radiation heart disease. Analysis of 16 young (aged 15 to 33 years) necropsy, patients who received over 3,500 rads to the heart. Am J Med. 1981; 70(3):519-30.

27. Nasso G, Canosa C, de Filippo CM, Modugno P, Anselmi A, Gaudino M, et al. Thoracic radiation therapy and suitability of internal thoracic arteries for myocardial revascularization. Chest. 2005; 128(3):1587-92.

28. Marks LB, Yu X, Prosnitz RG, Zhou S, Hardenbergh PH, Blazing M, et al The incidence and functional consequences of RT-associated cardiac perfusion defects. Int J Radiat Oncol. 2005; 63(1):214-23.

29. Heidenreich PA, Hancock SL, Vagelos RH, Lee BK, Schnittger I. Diastolic dysfunction after mediastinal irradiation. Am Heart J. 2005; 150(5):977-82

30. Adams MJ, Lipsitz SR, Colan SD, Tarbell NJ, Treves ST, Diller L, et al Cardiovascular status in long-term survivors of Hodgkin's disease treated with chest radiotherapy. J Clin Oncol. 2004; 22(15):3139-48.

31. Heidenreich PA, Hancock SL, Lee BK, Mariscal CS, Schnittger I. Asymptomatic cardiac disease following mediastinal irradiation. J Am Coll Cardiol. 2003; 42(4):743-9.

32. Glanzmann C, Kaufmann P, Jenni R, Hess OM, Huguenin P. Cardiac risk after mediastinal irradiation for Hodgkin's disease. Radiother Oncol. 1998; 46(1):51-62.

33. Handa N, McGregor CG, Danielson GK, Daly RC, Dearani JA, Mullany CJ, et al. Valvular heart operation in patients with previous mediastinal radiation therapy. Ann Thorac Surg. 2001; 71(6):1880-4.

34. Santoro F, Leva R, Lupo P, Pellegrino PL, Correale M, Di Biase M, et al. Late calcification of the mitral-aortic junction causing transient complete atrioventricular block after mediastinal radiation of Hodgkin lymphoma: multimodal visualization. Int J Cardiol. 2012; 155(3):e49-50.

35. Kaplan BM, Miller AJ, Bharati S, Lev M, Martin Grais I. Complete AV block following mediastinal radiation therapy: electrocardiographic and pathologic correlation and review of the world literature. J Interv Card Electrophysiol. 1997; 1(3):175-88.

36. Lindahl J, Strender LE, Larsson LE, Unsgaard A. Electrocardiographic changes after radiation therapy for carcinoma of the breast. Incidence and functional significance. Acta Radiol Oncol. 1983; 22(6):433-40.

37. Elerding SC, Fernandez RN, Grotta JC, Lindberg RD, Causay LC, McMurtrey MJ. Carotid artery disease following external cervical irradiation. Ann Surg. 1981; 194(5):609-15.

38. King LJ, Hasnain SN, Webb JA, Kingston JE, Shafford EA, Lister TA, et al. Asymptomatic carotid arterial disease in young patients following neck radiation therapy for Hodgkin lymphoma. Radiology. 1999; 213(1):167-72.

39. Cheng SW, Wu LL, Ting AC, Lau H, Lam LK, Wei WI. Irradiation induced extracranial carotid stenosis in patients with head and neck malignancies Am J Surg. 1999; 178(4):323-8.

40. Sharabi Y, Dendi R, Holmes C, Goldstein DS. Baroreflex failure as a late sequela of neck irradiation. Hypertension. 2003; 42(1):110-6.

41. Hassen-Khodja R, Kieffer E; University Association for Research in Vascular Surgery. Radiotherapy-induced supra-aortic trunk disease: early and longterm results of surgical and endovascular reconstruction. J Vasc Surg. 2004; 40(2):254-61.

42. Cormier F, Korso F, Fichelle JM, Gautier C, Cormier JM. [Post-irradiation axillo-subclavian arteriopathy: surgical revascularization]. J Vasc Dis. 2001; 26(1):45-9.

43. Lewis J, Roberts JT, Gholkar A. Subclavian artery stenosis presenting as posterior cerebrovascular events after adjuvant radiotherapy for breast cancer. Clin Oncol (R Coll Radiol). 1997; 9(2):122-3. 